\title{
Reproductive cycle of the pelagic fish Saurel Trachurus trachu- rus (Linnaeus, 1 758) (Perciformes Carangidae) Caught in the Gulf of Skikda (Algerian East Coast)
}

\author{
Souheila Azzouz ${ }^{*}$, Lyamine Mezedjri² \& Ali Tahar ${ }^{3}$ \\ ${ }^{1}$ Department of Biology, Faculty of Sciences, Badji Mokhtar University, 23000 Annaba, Algeria; e-mail: azzouz.souhi@yahoo.fr \\ ${ }^{2}$ Department of Natural Sciences and Life, Faculty of Sciences, University August 20, 1955, 21000 Skikda, Algeria; e-mail: me- \\ zedjri.lyamine@gmail.com \\ ${ }^{3}$ Laboratory of Vegetal Biology and Environment, Department of Biology, Faculty of Sciences, Badji Mokhtar University, 23000 \\ Annaba, Algeria; e-mail: pr_tahar_ali@hotmail.com \\ ${ }^{*}$ Corresponding author
}

ABSTRACT

KEY WORDS
The present study focuses on the reproductive biology of the small pelagic fish Saurel Trachurus trachurus (Linnaeus, 1758) (Perciformes Carangidae), fished in the Gulf of Skikda on the Algerian east coast on an annual cycle from July 2014 to June 2015. The study of average sex ratio variations gave an average annual value of $49.98 \%$ in favor of males. The gonado-somatic ratio and the macroscopic examination of the gonads allowed us to locate the period of reproduction between December and April. This report highlights a sexual cycle composed of three successive phases; a slow maturation started from July to November, a phase of significant sexual activity corresponding to the laying period (December-April) and a phase of sexual rest coinciding with the month of May when the gonads recover their masses. On a monthly basis, the evolution of the hepatosomatic ratio values is similar to that observed in the gonado-somatic ones, which leads us to believe that the origin of the energy reserves of the gonads is not the liver and that Saurel is a fat" fish, i.e. lipid accumulation occurs in the muscles. The study of mesenteric reserves confirmed the origin of gonadal energetic deposits. The size of the first sexual maturity in males and females is respectively 14 $\mathrm{cm}$ and $13.65 \mathrm{~cm}$.

Trachurus trachurus; Algerian east coast; reproduction; sex ratio; first sexual maturity.

Received 04.11.2018; accepted 06.01.2019; published online 20.03.2019.

\section{INTRODUCTION}

The study of the reproductive cycle of fish, including assessment of the reproductive potential is extremely useful to a better management of fisheries resources and to ensure the sustainability of these resources on the bioeconomic level.

Several studies have been devoted to various aspects of the small pelagic fish Saurel Trachurus trachurus (Linnaeus, 1758) (Perciformes Carangi- dae) (Letaconnoux, 1951; Maurin, 1954; Nikolsky, 1963; Lahaye, 1972; Macer, 1977; Fréon, 1984; Kartas \& Guignard, 1984; Korichi, 1988; Wootton, 1998; Mézédjri, 2004; Mézédjri \& Tahar, 2007; Robinson et al., 2008; FAO, 2013; Azzouz et al., 2015a, b, 2016, 2018).

In particular, the objective of this study is to establish a better understanding of the reproductive biology of Saurel T. trachurus in the Gulf of Skikda by studying the following parameters: sex Ratio, 
Gonado-somatic and Hepato-Somatic ratio, adiposity, size of first sexual maturity and condition factor (K) during the sexual cycle.

\section{MATERIAL AND METHODS}

The biological study consists in studying the parameters which make it possible to know the biology of our species; this study was carried out on fish caught by purse seines at the level of the Gulf of Skikda during the period stretching between July 2014 and June 2015.

Just with the unloading, at the port of Stora, a sample of 1 to $4 \mathrm{~kg}$ taken each month. On each fish we carried out a series of measures (Table 1). The measures of length were made by using a meter with a precision of $1 \mathrm{~mm}$, the total and emptied weights by means of a precision balance with an accuracy of $0.01 \mathrm{~g}$, the gonadic and hepatic weights were obtained using a balance of precision with an accuracy of $0.0001 \mathrm{~g}$.

The determination of sex and maturity stages was carried out according to the method recommended by ERH team (ERH, 1996), during the evaluation of national resources campaign. It consists in the determination of the maturity stages by means of a four-stage scale.

\section{$\mathrm{N}^{0}$ Code Description

1 Lt Total length \\ 2 Wt Total Weight \\ 3 We Eviscerated Weight \\ 4 Wgon Weight gonadic \\ 5 Whep Hepatic Weight \\ 6 Adip Adiposity \\ 7 Sex Identification of sex and}

Table 1. Measures done on fish for the reproduction survey.
For the species such as Sardine and Saurel, grease is white and covers the internal organs. To determine the degree of fattening, we used the empirical scale with four degrees recommended by the ERH team (ERH, 1996), which is a derivative of Nikolsky scale (Nikolsky, 1963).

\section{Sex-Ratio}

In our work used the formula which gives sexratio as a percentage by the following relation:

$$
S R=(\text { Males number } / \text { Total number }) \times 100
$$

Then, the chi-squared $\left(X^{2}\right)$ test was used to evaluate the variation of the actual values of the sexratio compared to the theoretical proportion $50 \%$ (Dagnélie, 2006). We supposed as hypothesis H0: sex-ratio $=50 \%$ and we tested this hypothesis by calculating the value $\chi^{2}$ obs.

$$
\chi^{2}=\left(m^{2} / F\right)+\left(f^{2} / F\right)-n
$$

With: $\mathrm{m}$ : males number, $\mathrm{f}$ : females number, $\mathrm{n}=$ $\mathrm{m}+\mathrm{f}, \mathrm{F}=\mathrm{n} / 2$ : absolute frequency for each sex.

When $\chi^{2}$ obs $\geq \chi^{2} 1-\alpha$ to 1 degree of freedom we rejected the null hypothesis $\mathrm{H} 0$ at the level $\alpha=0.05$. This test is valid only for number of males or females higher than 5 (Dagnélie, 2006).

\section{Gonado-Somatic Ratio GSR}

It is calculated starting from the relationship between the weight of the gonads (Wgon) and the eviscerated weight of fish (We). We used the weight of emptied specimens in the place of the total weight to eliminate the variations due to the repletion state of the stomach. The GSR was calculated for each individual according to the following formula (Kara, 1997):

$$
R G S=(W g o n / W e) \times 100
$$

This report allowed us to follow over time the weight changes that occur in the gonads during a reproductive cycle, which allows us to understand their maturation and to determine mainly the laying period (Barnabe, 1976). 


\section{Hepato-Somatic Ratio HSR}

This relationship is calculated between the hepatic weight (Whep) and eviscerated weight (We) according to the following formula (Kara, 1997):

$$
R H S=(\text { Whep } / \text { We }) \times 100
$$

\section{Adiposity}

Monthly variations of adiposity were assessed during the cycle of reproduction between July 2014 and June 2015. This made possible to follow the annual variations of the mesenteric greasy $(\mathrm{ERH}$, 1996).

\section{Size at First Sexual Maturity}

The size of the first sexual maturity shows the legal minimum size of the fish that can be fished in order to maintain sufficient fertility to regenerate the stock. It is determined to be the size corresponding to $50 \%$ of mature individuals. It is estimated by calculation, for each size class, with an interval of $1 \mathrm{~cm}$, and for each sex by considering the frequency of mature individuals in relation to the total number of the size class in question. The individuals concerned are only those caught during the Saurel breeding season, i.e. from December to April (Barnabe, 1976; Kara, 1997).

\section{Condition Factor $K$}

The condition factor $\mathrm{K}$ is an index allowing the assessment of the relative weight status of the studied individuals. According to Barnabe (1976), at equal size, fish of the same sex may have weight differences related to various factors such as feeding abundance or spawning period. It is expressed by the following relation:

$$
K=\frac{p}{L^{3}} \times 100
$$

or: $\mathrm{P}=$ eviscerated weight, $\mathrm{L}=$ total length.

In our case, we used the eviscerated weight to compensate the gonad weight fluctuations, as well as the calculated allometric no; to observe the monthly changes in $\mathrm{K}$. The global allometric coefficient calculated for each sex separately was also used to observe the variations of $\mathrm{K}$ as a function of a given class.

\section{RESULTS}

\section{Sex-ratio}

The monthly sex-ratio evolution revealed that out of a total of 923 examined individuals, there were 462 males and 461 females, giving a sex ratio of $49.98 \%$ in favor of males. This value is not significantly different from the theoretical value $\mathrm{SR}=$ $50 \%$ because $\chi^{2}=2.14$ and $\mathrm{P}>0.05$ therefore not significant at the level of $\alpha=5 \%$.

Overall, the sex ratio was still insignificant during the entire sampling period. During the months of October and January, we noted a sex ratio in favor of males with high significance at the level $\alpha=1 \%(\mathrm{P} \leq 0.01)$. Thus, in May the number of females was slightly higher than the number of males with a SR $=36.84 \%$ and $\chi^{2}=3.94$ (significant at the $\alpha=5 \%$ level; $\mathrm{p} \leq 0.05$ ) (Table 2).

\section{Monthly Variations of the Gonado-Somatic Ratio (GSR)}

Fluctuations in the gonado somatic ratio in $T$. trachurus showed a difference between the mean GSR values of females which were higher than those observed in males. In females we observed a downward phase extending from July 2014 $(\mathrm{GSR}=0.83 \%)$ to October $(\mathrm{GSR}=0.32 \%)$, followed by a net increase, from November (GSR $=$ $0.76 \%$ ) to the month of January 2015 (4.01\%). In February, the GSR values dropped significantly to reach $\mathrm{GSR}=0.37 \%$ in May, whereas growth restarted in June $(\mathrm{GSR}=3.83 \%)$.

In males there was a slight decrease during the months July, August and September 2014 (GSR from $0.53 \%$ to $0.28 \%$ ). GSR values began to increase in October (GSR $=0.54 \%$ ) up to January $2015(\mathrm{GSR}=2.05 \%)$. This value was followed by a decrease in the average value during the months of February, March, April, May and June when the growth reached its maximum value $(\mathrm{GSR}=4.59 \%)$ (Fig. 1). 


\begin{tabular}{|c|c|c|c|cc|}
\hline Month & N males & N femeles & Sex-ratio & $\chi 2$ 20bs & \\
\hline July-2012 & 43 & 63 & 40.5660 & $3.77358491 \quad$ ns \\
\hline August & 47 & 47 & 50.0000 & 0.00000000 & ns \\
\hline September & 46 & 41 & 52.8736 & $0.28735632 \quad$ ns \\
\hline October & 47 & 25 & 65.2778 & 6.72222222 & $* *$ \\
\hline November & 41 & 44 & 48.2353 & 0.10588235 & ns \\
\hline December & 46 & 37 & 55.4217 & $0.97590361 \quad$ ns \\
\hline January-2013 & 48 & 24 & 66.6667 & 8.00000000 & $* *$ \\
\hline February & 37 & 40 & 48.0519 & 0.11688312 & ns \\
\hline March & 35 & 41 & 46.0526 & $0.47368421 \quad$ ns \\
\hline April & 30 & 38 & 44.1176 & $0.94117647 \quad$ ns \\
\hline May & 21 & 36 & 36.8421 & $3.94736842 \quad *$ \\
\hline June & 21 & 25 & 45.6522 & 0.34782609 & ns \\
\hline Total & 462 & 461 & 49.9798 & 2.14099064 & ns \\
\hline
\end{tabular}

Table 2. Monthly sex ratio changes at Saurel in the Gulf of Skikda (Algeria) with $\mathrm{p}>\alpha=0.05$ : (ns) not significant, $\mathrm{p}$ $\leq \alpha=0.05:\left(^{*}\right)$ significant, $\mathrm{p} \leq \alpha=0.01:(* *)$ highly significant.

\section{Monthly variations of the Hepato-Somatic Ratio (HSR)}

As shown in figure 2, we observed, in females, the lowest values of HRS during the month of July 2014 until December (HSR $=0.58 \%$ and $0.70 \%$, respectively), with a maximum recorded in March (RHS $=2.04 \%$ ); then again a decreasing trend from April $(\mathrm{RHS}=1.53 \%)$, to May $(\mathrm{HSR}=1.08 \%)$ and in June (HSR $=1.29 \%)$.

In males, variations in HSR were similar but with values slightly lower than in females. The lowest values were observed around July 2014, September, October, November and December. There was an increase in the value of the report in January 2015 (HSR $=0.90 \%)$ until reaching the maximum value in March $(\mathrm{HSR}=1.98 \%)$, then there was a fall in HSR values in April, May and June (down to $0.89 \%)$.

\section{Monthly Variations of Adiposity}

The monthly variations of adiposity in females as in males were observed. The highest peak was recorded in the month of November (adiposity $=$ $2.00 \%$ ), then the values decreased to the lowest threshold (adiposity $=1.00 \%$ ) during the breeding season. Then another peak was recorded in April in females (adiposity $=1.45 \%$ ) and in May for males (adiposity $=1.57 \%$ ) then, again, a decreasing trend was observed (Fig. 3).

\section{Size of the First Sexual Maturity}

The evolution of the size of the first sexual maturity given by class size of the mature individuals according to the total length during the reproduction period (December/April) in T. trachurus where the gonads are at their maximum development, showed that the male Saurel from the Gulf of Skikda starts to participate in breeding at a size of $\mathrm{Lt} 50=14 \mathrm{~cm}$ (Fig. 4) and for the female Saurel Lt 50 $=13.65 \mathrm{~cm}$ (Fig. 5), so we did not observe significant difference between the size of the first sexual maturity of males and females.

\section{Condition factor $K$}

The average condition factor $\mathrm{K}$ ranged between $\mathrm{K}=0.67$ and $\mathrm{K}=0.79$ during the period under investigation, reflecting the general state of the fish as a function of physiological activities. We noted that the evolution of this index during the year was slightly stationary from July 2014 to June 2015. The highest value was recorded in March $(\mathrm{K}=0.79)$ which reflects the good condition of Saurel whereas the minimum was observed in February $(\mathrm{K}=0.67)$ showing a slight weight loss of fish (this is the period during which the laying takes place) (Fig. 6).

Variations in k-class size coefficients in males were slightly different from in females. The mean value recorded in males $(\mathrm{K}=0.72)$ was the same value as that in females. These variations had no distinct appearance (Fig. 7)

\section{DISCUSSION}

The study of the sex-ratio variations during the period from July 2014 to June 2015 of the Saurel $T$. 


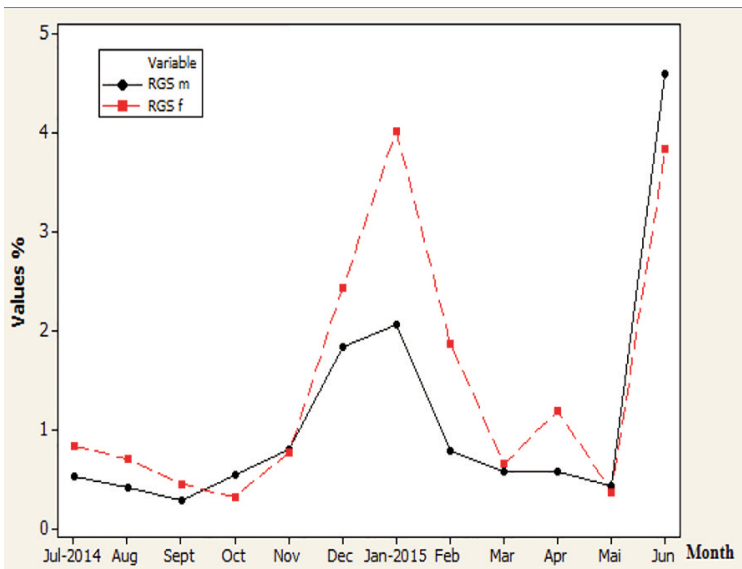

Figure 1. Monthly variations of GSR in Trachurus trachurus.

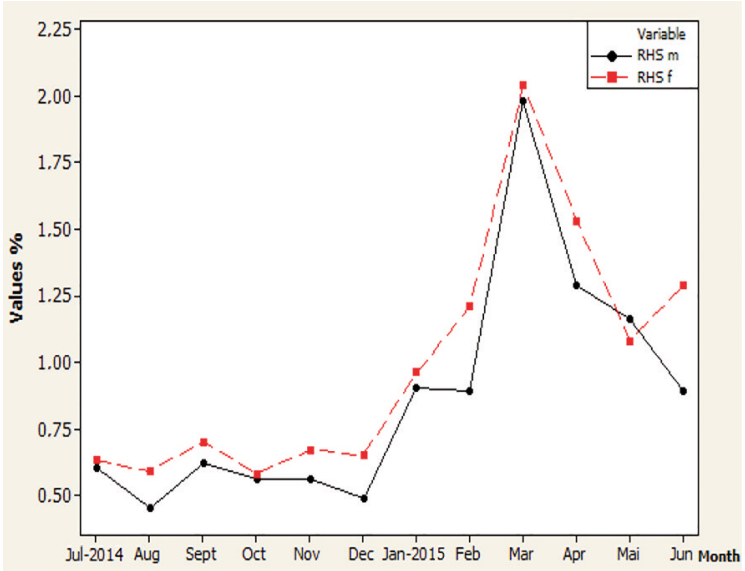

Figure 2. Monthly variations of HSR in Trachurus trachurus.

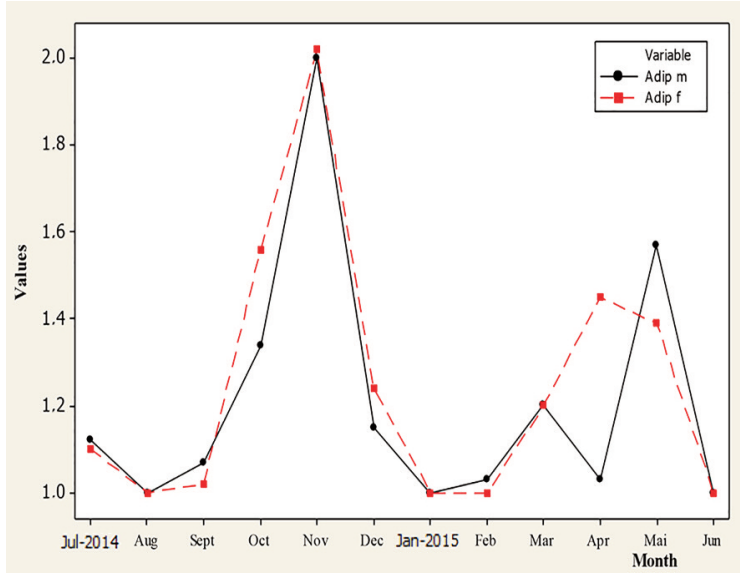

Figure 3. Monthly variations of adiposity in Trachurus trachurus.

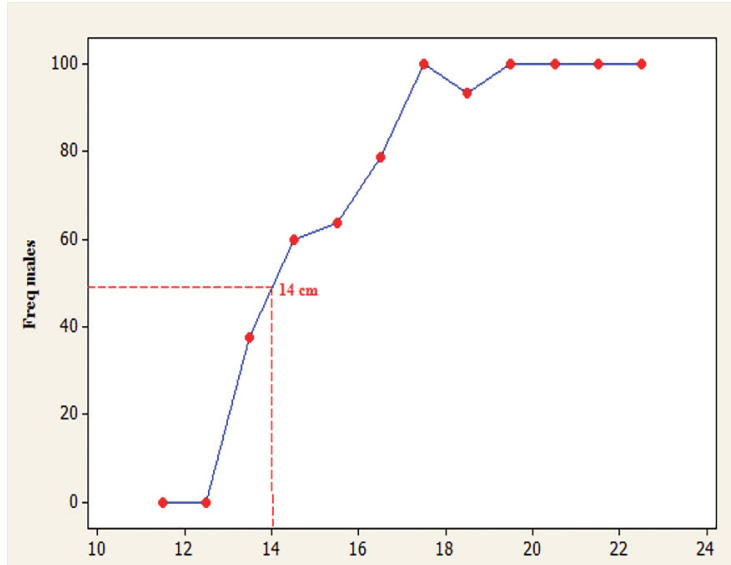

Figure 4. Size of first sexual maturity in males of Trachurus trachurus.

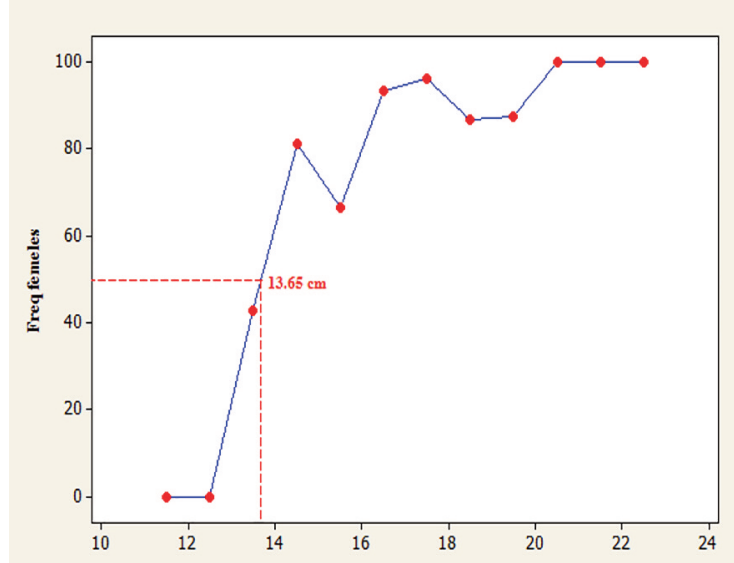

Figure 5. Size of first sexual maturity in females of Trachurus trachurus.

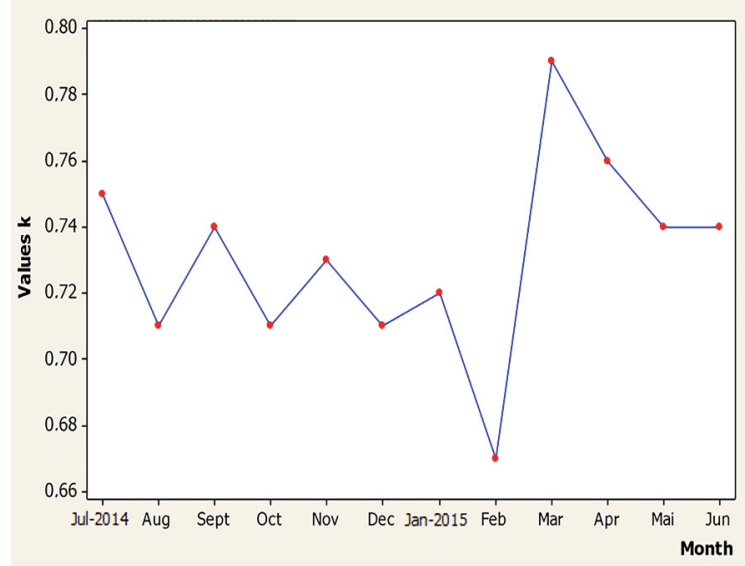

Figure 6. Monthly variations of $\mathrm{K}$ in Trachurus trachurus. 


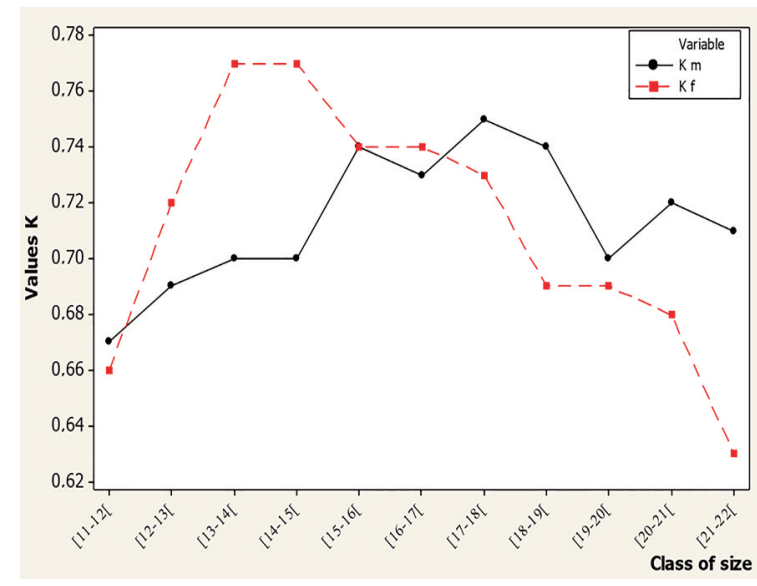

Figure 7. K Variations by Sex and Size classes in Trachurus trachurus.

trachurus of the Gulf of Skikda gave an average annual value of $49.98 \%$ in favor of the males, so overall, the males and the females were presented by almost equal proportions. Male sex ratio values were dominant in summer and fall, while females were dominant in winter and spring when breeding occurs.

Monitoring the monthly changes in GSR provides information on the periods of sexual activity and allowed us to establish that the saurel breeding season in our region occurs between December and April. GSR levels of females were higher than those of males because of the large size of the ovaries.

The values obtained for the evolution of the GSR showed that the studied sexual cycle comprises three phases: 1) slow maturation phase extending from the month of July and going on until the month of November when the GSR reaches the lowest values; 2) a phase of intense sexual activity from December to April, which is the period of laying where the RGS reaches the maximum; and 3) a phase of sexual rest that coincides with the month of May when the testicles and the ovaries recover their mass.

The peak observed in June 2015 was probably related to climate change and the high temperature recorded during the summer of 2015, so a breeding phase in Saurel was, probably, triggered.

The study of the monthly variations of the HSR showed that the necessary energy for the maturity of the gonads comes from the lipid reserves stored at the level of the liver. In both sexes one has the same pace but with slightly lower values in the males. In general, during the maturation period, we had the lowest values of HSR followed by an increased peak of HSR during the breeding season. Therefore, these HSR variations showed an evolution almost similar to that of the GSR with maximum and minimum values reached at the same time, which suggests that the species is a fatty fish for which lipid accumulation occurs in the muscles (Bertin, 1958), and the liver does not intervene in the transfer of energy reserves (Djabahi \& Hamida, 1989). As the liver plays no part in the process of maturation of sexual products, this implies that the two parameters (GSR, HSR) should be studied together and not separately, so these two indices are to be considered a good indicator of the metabolic state and energy reserves of fish.

With regard to mesenteric fat stores, values generally fluctuated throughout the sexual cycle in Saurel, there was a maximum peak implying an accumulation of reserves during the period of sexual rest and, still, maturation was followed by very low fat levels during the reproduction period, which confirms the origin of gonadal reserves (Djabali \& Hamida, 1989).

The study of the size of the first sexual maturity based on the frequency of the mature individuals as a function of the total length ( Lt 50) for which $50 \%$ of the individuals of the population are able to reproduce, made it possible to assess that for the males of T. trachurus the size of the first sexual maturity in the Gulf of Skikda during the studied period, July 2014-June 2015, is estimated as Lt 50 $=14 \mathrm{~cm}$ for males and Lt $50=13.65 \mathrm{~cm}$ for females.

The monthly evolution of this coefficient $(\mathrm{K})$ in the Saurel T. trachurus of the Algerian east coast is slightly stationary throughout the sexual cycle, the lowest value showing a slight weight loss noted during the month of February which coincides perfectly with the period of laying where the reserves energy is consumed, followed by an increase in the value of $\mathrm{K}$ in the month of March, where the fish quickly recover their weight during the sexual rest period.

\section{CONCLUSIONS}

The biological study of the reproduction of Saurel samples taken from the Gulf of Skikda (Al- 
gerian east coast) during the year July 2014 to June 2015 shows that: the reproduction of horse mackerel T. trachurus takes place once a year, apparently from December to April. The study of the sex-ratio shows that the males dominate $(\mathrm{SR}=$ $49.98 \%$ ) The values obtained on the evolution of the Gonado-Somatic Ratio show that the sexual cycle studied passes by three successive phases, a phase of slow maturation, a phase of intense sexual activity and a phase of sexual rest. Variations of the Hepato-Somatic Ratio leads us to believe that the origin of the energetic reserves of the gonads is not the liver but, rather the muscles. The size of the first sexual maturity is reached at a length of $14 \mathrm{~cm}$ in males and females $13.65 \mathrm{~cm}$. The monthly change in the condition factor $(\mathrm{K})$ shows that our Saurel fish makes its energy reserves available during the breeding season and stores them during sexual rest.

\section{REFERENCES}

Azzouz S., Tahar A. \& Mezedjri L., 2015a. Influence des facteurs environnementaux sur la variabilité morphologique du Saurel Trachurus trachurus (Linnaeus, 1758) du littoral algérien. 6ème Journées Scientifiques Internationales sur la Valorisation des bioressources. Monastir, Tunisie (1-3 Mai 2015). Abstract book.

Azzouz S., Tahar A. \& Mezedjri L., 2015b. Contribution à l'étude des caractères morphométriques d'un poisson téléostéen le Saurel Trachurus trachurus (Linnaeus, 1758) du littoral algérien. IIIème Congrès International de Biotechnologie et Valorisation des Bio-Ressources (AT-BVBR). Tabarka, Tunisie (2023 Mars 2015). Abstract book.

Azzouz S., Mezedjri L. \& Tahar A., 2016. Approche Morphométrique Comparée pour Identifier les Peuplements du Saurel Trachurus trachurus (Linnaeus, 1758) du littoral algérien. 6ème Colloque International Sciences \& Environnement. Bizerte, Tunisie (21-23 Mars 2016). Abstract book.

Azzouz S., Mezedjri L. \& Tahar A., 2018. Comparative study on Saurel Trachurus trachurus fish (Linnaeus, 1758) obtained from the Algerian littoral using multivariate statistical methods (principal component analysis and hierarchical analysis). Journal of Biodiversity and Environmental Sciences, 13: 54-62, 2018. http://www.innspub.net.

Bertin L., 1958. Sexualité et fécondation. In: Grassé P. P. (Ed.),Traité de Zoologie, Masson, Paris, 13.2: 15841652.
Barnabe G., 1976. Contribution à la connaissance de la biologie du loup Dicentrarchus labrax (L.) (Poisson Séraranidé). Thèse d'état, Université Montpellier Sciences et Techniques du Languedoc, 426 pp.

Dagnélie P., 2006. Statistique théorique et appliquée. Tome 2: Inférences à une et à deux dimensions. Bruxelles, Université De Boeck \& Larcier, 659 pp.

Djabali F. \& Hamida F., 1989. Pelagos. Bulletin de l'Institut des Sciences de la Mer et de l'Aménagement du Littoral, ISMAL, 7: 11-26.

ERH, 1996. Evaluation de la ressource halieutique. Ministère des pêches et des ressources halieutiques. Rapport Campagne1996, 40 pp.

FAO, 2013. Species Fact Sheets Trachurus trachurus (Linnaeus, 1758), Food and Agriculture Organization of the United Nations. Fisheries and Aquaculture Department.

Fréon P., 1984. La variabilité des tailles individuelles à l'intérieur des cohortes et des bancs de poisson, lére partie: observation et interprétation. Oceanologica Acta, 7: 457-468.

Kara M.H., 1997. Cycle sexuel et fécondité du loup Dicentrarchus labrax (poisson Moronidé) du golfe d'Annaba. Cahiers de Biologie Marine, 38: 161-168.

Kartas F. \& Guignard J. P., 1984. La fécondité des poissons Téléostéens. Ed. Masson, 121 pp.

Korichi H.S., 1988. Contribution à l'étude biologique des deux espèces de Saurels: Trachurus trachurus (Linnaeus, 1758) et Trachurus méditerraneus (SteinDachner, 1868) et de la dynamique de Trachurus trachurus (Linnaeus, 1758) en baie de Bou-Ismail (Alger).Thèse de magister, ISMAL, Alger, 203 pp.

Lahaye J., 1972. Cycles sexuels de quelques poissons plats des côtes de bretonnes. Revue des travaux de l'Institut des pêches maritimes, 36: 191-207.

Letaconnoux R., 1951. Contribution à l'étude des espèces du genre Trachurus et spécialement du Trachurus trachurus (Linnaeus, 1758). Office Scientifique et Tecnique de Maritimes, Mémoire 15, 70 pp.

Macer C.T., 1977. Some aspect of the biology of the horse mackerel (Trachurus trachurus) in water around Britain. Journal of Fish Biology, 10: 61-62.

Maurin C., 1954. Les merlus du Maroc et leur pêche. Bulletin de l'Institut des pêches Maritimes du Maroc, Casablanca, 2: 7-65.

Mézédjri L., 2004. Etude Biologique et Biométrique Comparée de l'anchois Européen Engraulis encrasicolus dans le golfe de Stora (Skikda) et le golfe de Lion (France). Mémoire de magister, Université Badjii Mokhtar, Annaba, 106 pp.

Mezedjri L. \& Tahar A., 2007. Morphological variability, between two sites in Mediterranean population of the European anchovy: Engraulis encrasicolus. Journal of Fisheries International, 2: 65-68. https://doi.org/ jfish.2007.65.68 
Nikolsky G.V., 1963. The ecology of fishes. Academy press, London and New York, 352 pp.

Robinson M.S., Anthony T.R., Littau S.R., Herckes P., Nelson X., Poplin G.S. \& Burgess J.L., 2008. Occupational PAH exposures during prescribed pile burns. Annals of Occupational Hygiene, 52: $497-$ 508.

Wootton R.J., 1998. Ecology of teleost fishes. Second edition. Fish and Fischeries, series 24. Dordrecht, Kluwer Academic Publishers, 386 pp. 